\title{
Bullet Embolism of Pulmonary Artery: A rare case
}

\author{
Pulmoner Arter Kurşun Embolisi: Nadir Bir Olgu
}

\author{
Ozan Akinci ${ }^{1}$ Ozlem Gungor ${ }^{2}$ Sefa Ergun ${ }^{3}$ \\ ${ }^{1}$ Istanbul Kartal Dr. Lütfi Kirdar City Hospital, Department of General Surgery, Istanbul \\ 2Istanbul Sancaktepe Training and Research Hospital, Department of Radiology, Istanbul \\ ${ }^{3}$ Istanbul University-Cerrahpasa, Cerrahpasa Medical Faculty, Department of General Surgery, Istanbul
}

\begin{abstract}
Bullet embolism of pulmonary artery is a vascular traumatic entity that is a very rare but with serious complications. The bullet can lead to vascular embolism by entering directly into the intravascular area or by migration. In pulmonary artery bullet embolism, complications with high mortality such as thrombosis, sepsis, endocarditis, cerebral stroke may be encountered. Observation and follow-up are sufficient in asymptomatic venous bullet embolism cases. In this case report, we aimed to share our experience with a patient who developed a bullet embolism of pulmonary artery as a result of gunshot injury from the right iliac region.
\end{abstract}

Key Words: Bullet embolism; gunshot injury; pulmonary artery.

\section{Objective}

Bullet embolism is a rare but serious complication of penetrating vascular trauma and it is an extraordinary clinical experience for trauma surgeons. Migration of bullets into pulmonary vascular structures can lead to infection, thrombosis, ischemia, bleeding, or death $(1,2)$. Almost all cases of pulmonary bullet embolism reported in the literature as a case report are arterial embolism and may result in early ischemia findings $(1,3)$. Venous bullet embolism is a rarer phenomenon and generally asymptomatic (3). In cases where there is a difference between the number of bullet entry wounds and the number of exit wounds in patients presenting with gunshot injury, the risk of bullet embolism should be considered. In this case report, we aimed to discuss a patient in whom we detected venous bullet embolism in the lower lobe of right lung segmental pulmonary artery as a result of gunshot injury.

\begin{abstract}
Özet
Pulmoner arter kurşun embolisi oldukça nadir görülen fakat ciddi komplikasyonlar1 olan vasküler travmatik bir antitedir. Kurşun doğrudan intravasküler alana girerek veya migrasyon ile vasküler embolizme yol açabilir. Pulmoner arter kurşun embolisinde tromboz, sepsis, endokardit, serebral stroke gibi yüksek mortaliteli komplikasyonlar ile karşılaşılabilir. Asemptomatik venöz kurşun embolisi olgularında gözlem ve takip yeterlidir. Bu olgu sunumumuzda iliak bölgeden ateşli silah yaralanması sonucu pulmoner arter kurşun embolisi gelişen bir hasta ile ilgili deneyimimizi paylaşmayı amaçladık.
\end{abstract}

Anahtar Kelimeler: Kurşun embolisi; ateşli silah yaralanması; pulmoner arter.

\section{Case Report}

A 25-year-old male patient was brought into the emergency room with a gunshot injury on the right hip. Glasgow coma scale score was 15. As a result of the physical examination, there was one bullet entry and one bullet exit wound in the right gluteal region. In addition, there was one more bullet entry wound without an exit in the $1 \mathrm{~cm}$ medial of the right anterior superior iliac spine. Pelvic computed tomography (CT) showed cortical irregularity in the right iliac bone, multiple free bone fragments of millimetric size within the surrounding soft and muscle tissue, and a foreign body structure compatible with several hyperdense structures (Figure 1). Irregularities were observed in the right iliac vein wall. No significant extravasation or hematoma was observed. In thorax CT, an image of metallic density was detected in the sagittal and horizontal sections of the segmental pulmonary artery in the lower lobe of right lung (Figure 2). No hemothorax or

*Sorumlu Yazar: Ozan Akıncı Istanbul Kartal Dr. Lütfi Kırdar City Hospital, Department of General Surgery, Kartal, Istanbul, Turkey. Email: ozanakinci1987@hotmail.com Orcid: Ozan Akınc1: 0000-0002-7149-6854, Özlem Güngör: 0000-0002-6615-4892, Sefa Ergün 00000002-0315-8044 


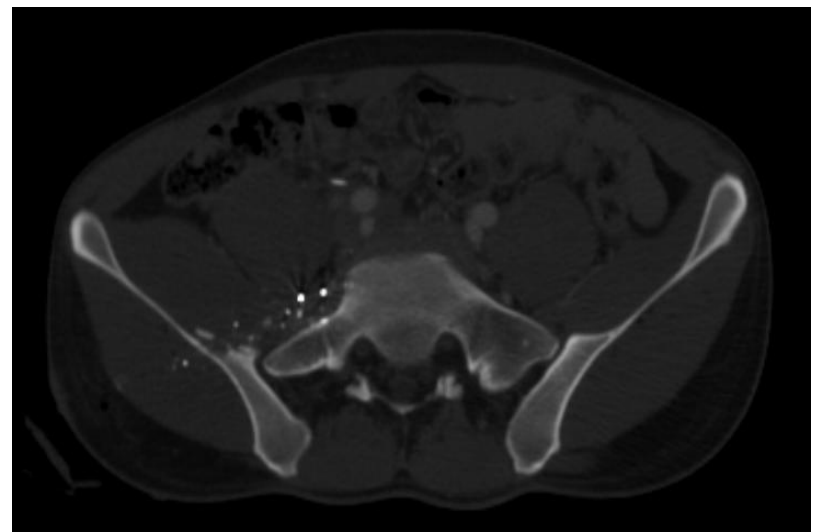

Figure 1. Cortical irregularity in the right iliac bone, and foreign body structures in soft and muscle tissue in pelvic CT.

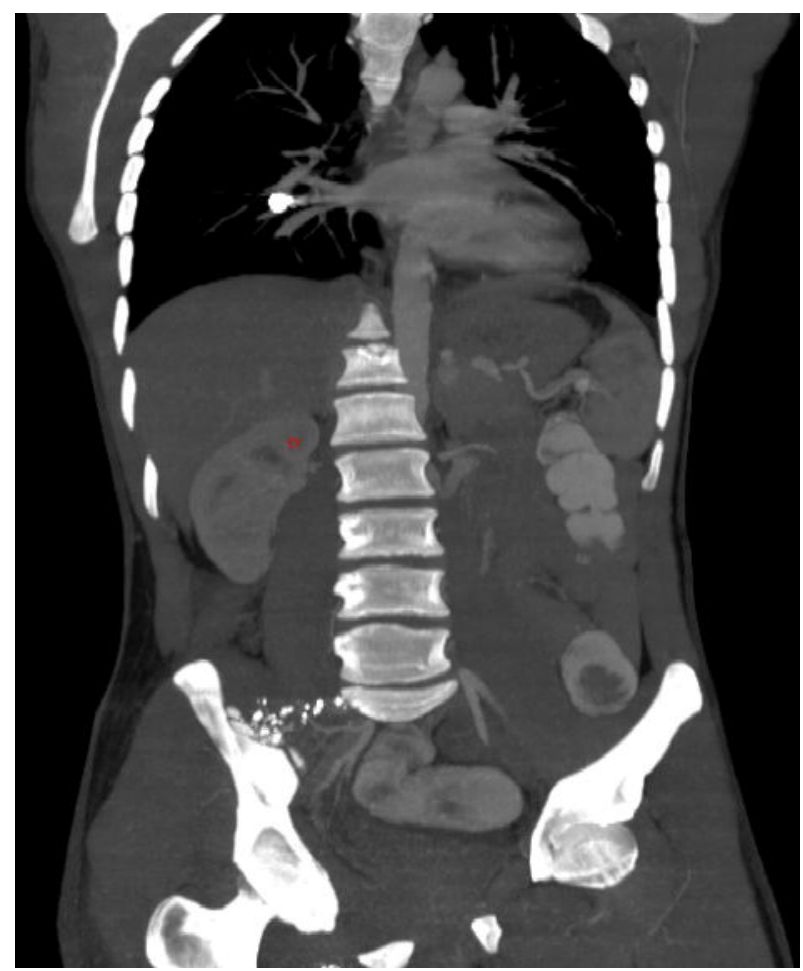

Figure 2. Metalic density image in pulmonary artery in thorax CT horizontal section.

pneumothorax was detected. The patient was monitored and taken under observation. Since he was asymptomatic during the observation period, no surgical intervention was considered. Patient discharged after three days of observation. A ballistic examination revealed that the injury was carried out with a low-speed, small-caliber gun. On the $13^{\text {th }}$ day the patient didn't have any symptoms and on thorax CT the images of bullets in the pulmonary artery remained in the same localization. Later, the patient walked out of follow-up because he felt well and did not have any complaints. Informed consent was obtained from the patient for this study.

\section{Discussion}

Bullet embolism develops as a small-caliber, the low-speed bullet enters the vascular bed and gets into the bloodstream (1). It was encountered in $0.3 \%$ of 7500 gunshot injuries that occurred in the Vietnam War (3). In most of the gunshot injuries, two bullet wounds are expected, the entry and exit wounds. In gunshot injuries without an exit wound as in our case, bullet embolism should be considered in the differential diagnosis. In our case, although there were two bullet entry wound, one exit wound was detected. Bullet embolism can be of three types: arterial, venous, and paradoxical. Arterial embolism accounts for $80 \%$ of cases of bullet embolism (2). In arterial embolism, early complications of ischemia are seen. Although venous embolism is less common and generally asymptomatic, sometimes it can lead to serious complications such as cardiac valve injury, endocarditis, sepsis, venous thrombosis, thrombophlebitis and arrhythmia (1-3). Paradoxical bullet embolism describes that the bullet get into arterial circulation through an intracardiac defect or a traumatic arteriovenous fistula while of venous origin (4). In our case, a bullet was assumed to have entered the vascular bed from the right iliac vein due to irregularity in wall at this point. Chest X-ray, computed tomography, angiography, transthoracic or transesophageal echocardiography are helpful in the diagnosis (5). There is no consensus on the treatment algorithm of pulmonary artery bullet embolism. Anatomic location, the timing of diagnosis, and the presence of symptoms are determinative in the treatment approach. There are different approaches, namely thoracotomy and arteriotomy, thoracotomy and lobectomy, endovascular extraction, or observation (1-3). In a study conducted by Kortbeek et al. (6), it was reported that $44 \%$ of pulmonary artery bullet embolism cases can be managed successfully only by monitoring. According to Miller et al. (2), while surgical intervention is mandatory for an intracardiac bullet, the patient's monitoring and control is sufficient for cases of asymptomatic pulmonary artery bullet embolism. The recent evolution of endovascular techniques for bullet retrieval has decreased the need for open thoracotomy and reduced the complications associated with embolectomy (7). In our case, we preferred the observation since bullet embolism located in the right pulmonary artery branch didn't 
cause any symptoms in the patient, and no complications occurred in the follow-up period.

In conclusion, bullet embolism of the pulmonary artery should be kept in mind especially in gunshut injuries without exit wounds. In asymptomatic cases, observation and radiological follow-up are sufficient.

Author contributions: Determining the main idea of the article: Ozan Akinc1; Literature review: Ozan Akınc1, Özlem Güngör, Sefa Ergün; Writing your article: Ozan Akınc1, Sefa Ergün. Material selection: Made by Özlem Güngör.

Declaration of conflicting interests: The authors declared no conflicts of interest with respect to the authorship and/or publication of this article.

Funding: The authors received no financial support for the research and/or authorship of this article.

\section{References}

1. Agarwal SK, Singh A, Kathuria M, Ghosh PK. Wandering bullet embolizing to the pulmonary artery : a case report. Asian Cardiovasc Thorac Ann 2007; 15(2): 154-156.

2. Miller KR, Benns MV,Sciarretta JD,Harbrecht BG, Ross CB, Franklin GA, et al. The evolving management of venous bullet emboli: a case series and literature review. Injury 2011; 42(5): 441-446.

3. Fernandez-Ranvier GG, Mehta P, Zaid U, Singh K, Barry M, Mahmoud A. Pulmonary artery bullet embolism- Case report and review. Int J Surg Case Rep 2013; 4(5): 521 523.

4. Govindaraju RC, Kolwalkar JP. Missile embolism from pulmonary vein to systemic circulation: case report with systematicliterature review. J Emerg Trauma Shock 2019; 12(3): 218-221.

5. Yamanari MG, Mansur MC, Kay FU, Silverio PR, Jayanthi SK, Funari:MB. Bullet embolism of pulmonary artery: a case report. Radiol Bras 2014; 47(2): 128-130.

6. Kortbeek JB, Clark JA, Carraway RC. Conservative management of a pulmonary artery bullet embolism: case report and review of the literature. J Trauma 1992; 33(6): 906-908.

7. Duke E, Peterson AA, Erly WK. Migrating bullet: A case of a bullet embolism to the pulmonary artery with secondary pulmonary infarction after gunshot wound to the left globe. J Emerg Trauma Shock 2014; 7(1): 38-40. 